\title{
SOBRE EL OFICIO LITERARIO Y AUDIOVISUAL DEL GUIONISTA DE FICCIÓN
}

\section{On the Literary and Audiovisual Work of Fiction Screenwriter}

\author{
AUTORES: ZURIAN, Francisco A. \\ Profesor Contratado Doctor - Universidad Complutense de Madrid - España \\ azurian@ucm.es
}

\section{Resumen}

El texto se adentra en un campo de estudio que suele ocupar poco espacio en las revistas o textos académicos: la escritura de guión de ficción y si esa escritura se puede considerar un oficio audiovisual y/o literario. Para ello se analiza la bibliografía existente (muchas veces enfocadas más desde un punto de vista profesional que académico) y las diversas posturas que se mantienen sobre el lugar del guión en el ámbito audiovisual que por medio del planteamiento de seis preguntas básicas se establece una reflexión sobre el oficio, la vocación, la valoración y los hábitos del guionista tanto como escritor como cineasta. Se trata, de este modo, de un ensayo que intenta apostar y reivindicar la posición del cineasta en la industria audiovisual y reclamar también su rol de escritor, fundamentando el sentido de su trabajo y su posición en la industria audiovisual, poniendo en juego las aportaciones de escritores, cineastas, guionistas y académicos que, previamente, han reflexionado sobre estos temas y construyendo una línea argumental clara que concluye de forma manifiesta con la apuesta de reconocimiento real al guionista y su trabajo en el universo de la creación ficcional.

\begin{abstract}
The text is entered in a field of study that usually occupies little space in academic texts: writing fiction screenplay and if that script can be considered an audiovisual trade and / or literary. For this, the literature is discussed (often focused more from a professional point of view tan academics) and the various positions that are maintained on the place of the script in the audiovisual field by the approach of six basic questions reflection is established on the job, vocation, valuing and habits of both a writer and screenwriter filmmaker. It is, thus, an essay that attempts bet and claim the position of director in the audiovisual industry and also reclaim his role as a writer, basing the meaning of work and claiming his position in the audiovisual industry, jeopardizing the contributions of writers, filmmakers, writers and academics who have previously thought about these issues, relating them and building a clear storyline concludes clearly with the commitment of recognizing the writer in the universe of fictional creation.
\end{abstract}

\section{Key words}

Escritura; guión; guionista; ficción; audiovisual.
Writing; screenplay; screenwriter; fiction; audiovisual.

\section{1. ¿Vocación vs. oficio?}

Cuando escribo un guión me dejo llevar por el instinto. Si me aburro, el publico se aburrirá, si no me emociona lo que escribo, el publico tampoco se emocionara. En esos casos me tomo un respiro y un par de días después vuelvo al guión e intento descubrir que era lo que no funcionaba. Entonces se me ocurre que debería entrar en escena un nuevo personaje o lo que sea. Gran parte de este proceso es intuitivo y, me temo, algo que no puede enseñarse. Puedes enseñar gramática y a escribir frases claras con un principio y un final, pero no puedes enseñar escritura creativa. Leo con voracidad para compensar mi carencia de una educación formal. Si alguien quiere ser guionista tiene que leer novelas. Los aspirantes a guionistas también tienen que ir al cine, a ver obras dramáticas al teatro, que son fundamentales por la estructura en tres actos. 
Pero, sobre todo, lo que tienen que hacer es pelarse el trasero sentados delante de la máquina de escribir. Y tienen que hacerlo así porque la única manera de aprender de verdad a escribir es escribiendo.

(George Axelrod en McGrath \& MacDermott, 2003: 28 y 31)

Suele existir un halo de cierta genialidad que rodea a los oficios artísticos y que suele generar un (estéril) debate en torno a la escritura como vocación y/o como oficio, puesto que, inevitablemente, escribir (ficción o no) necesita tanto de habilidades como de destrezas que requieren, necesariamente, ir aprendiéndose, desarrollándose e incorporándose, con naturalidad, a su quehacer cotidiano. Estar tocado por el "don" de la escritura o contar con el beneplácito de las "musas" o contar con el "genio" de la expresividad no dejan de ser, en sí mismas, ideas románticas que no sirven para nada puesto que, o bien sirven para dejar el trabajo (porque no se cuenta con dichas "gracias"), o para holgazanear (esperando a que "llegue" la "inspiración"). Sócrates decía que "las obras de los poetas no son producto de la sabiduría, sino de un don natural, y los poetas están inspirados como los profetas y los oráculos" (Grube, 1984: 276). Pero, como toda actividad humana, escribir requiere, efectivamente, de unas cualidades pero, también, de un aprendizaje para que dichas cualidades puedan desarrollarse. "Es imposible aprender a escribir", "el escritor nace". No dejan de ser ideas comunes que no significan realmente nada.

Con frecuencia se pregunta si es posible aprender a escribir. La respuesta tiene dos partes: el talento es requisito previo, pero la persona talentosa puede y debe aprender a escribir. En realidad, el grado de talento que uno posee no puede determinarse hasta que la pericia favorece su expresión. (Vale, 1996: 15-16)

Obviamente se pueden aprender y se pueden desarrollar, mediante el esfuerzo, unas posibles inclinaciones naturales. Como afirmaba el novelista e historiador británico Walter Besant (2006: 17-18) la ficción "es un arte que $[\ldots]$ es gobernado y dirigido por leyes generales; y que puede decirse que estas leyes se pueden establecer y enseñar con tanta precisión y exactitud como las leyes de la armonía, la perspectiva y la proporción", lo que no significa, empero, que sea como un "arte simplemente mecánica” (que sea como una simple artesanía), es decir, que sea un conjunto de normas a cumplir sin más. Besant afirma que "ninguna ley o regla puede enseñarla a aquellos que no han sido dotados con los talentos naturales y necesarios"; esto es, según él, se necesita un "algo" (inclinación o talento "natural") previo sobre el que construir su enseñanza. Pero es evidente que, por mucha "inclinación" que se tenga a algo, si no se trabaja, esa inclinación no lleva a ningún lado. La escritora norteamericana Edith Wharton parece referirse a esa inclinación natural al distinguir entre "imaginación meramente comprensiva" e "imaginación creativa":

La diferencia principal entre la imaginación meramente comprensiva y la imaginación creativa es que esta última tiene dos aspectos y que combina el poder de penetrar en otras mentes con el de elevarse suficientemente por encima de ellas para ver más allá y relacionarlas con todo el conjunto vital del que emergen parcialmente. Esta visión global sólo puede obtenerse elevándose a cierta altura: y esa altura, en el arte, es proporcional al poder que tiene el artista de despegar una parte de su imaginación del problema particular en el que el resto está sumergido. (Wharton, 2012: 24-25)

El escritor, la escritora, necesita tener esa imaginación creativa (e intuitiva, podríamos decir) y, a la vez, debe educarse para desarrollarla al máximo y es que puede existir vocación, pero sin oficio no se llega a ningún lado. Y puede que no se tenga vocación (inclinación o como se quiera llamar) pero con oficio se puede desarrollar un buen trabajo de escritura.

La escritura de guiones, como cualquier proceso creativo, es una mezcla de habilidades, conocimientos, experiencia y suerte. (Parker, 2003: 23)

Y, así, con imaginación creativa, con formación y con trabajo se puede desarrollar la profesión de escritor que irá, de ese modo, desarrollando su propia y personal visión gracias a la "riqueza acumulada de 
conocimiento y sabiduría" porque "la verdadera originalidad no consiste en una nueva manera, sino en una nueva visión" (Wharton, 2012: 26) y el primer trabajo del escritor es construir, precisamente, su propia visión, su propio mundo, desde el que escribirá y ofrecerá su perspectiva personal de las personas y de la vida por medio de sus personajes y de sus historias.

\section{2. ¿La obra del guionista es una obra literaria?}

Otro viejo (y también estéril) debate es si escribir guiones (o ser guionista) es un trabajo literario o no. ¿Es el guión una "obra” literaria o no? Pero, realmente, ¿qué añade o qué aporta esa pregunta y su (posible) respuesta? Normalmente se ha considerado al guionista (o al fruto de su trabajo, el guión) como ajeno a toda labor literaria; el problema es que dicha opinión lo que ha pretendido afirmar es que el trabajo del guionista es ajeno a "lo" artístico, consiguiendo un menoscabo evidente en su valoración social y profesional. Seguramente apoyados en la parquedad de su lenguaje, en su escritura nada florida, y en que el guión no es nunca un fin intrínseco en sí mismo sino que su fin es construir, usándolo como una herramienta, una historia que se desarrollará en imágenes bajo la guía de un director y con el trabajo de producción y todo el desarrollo técnico necesario.

Evidentemente esos argumentos alejan del aura de artisticidad literaria al guión audiovisual y, por ello, tradicionalmente, se ha situado al guionista al lado de lo artesano y no de lo artístico.

La memoria suele ser olvidadiza pero habría que recordar lo que antes ha ocurrido con otras formas de escritura, como el teatro. Tampoco ayuda el hecho de que no sin dificultad se puede acceder a la lectura de guiones ${ }^{i}$ y cuando se puede acceder, su lectura es sumamente árida y abstracta, de ahí que Rohmer la calificara de "informe" y "esquelética" (Guerin, 2004: 71).

\section{SECUENCIA 01. EXTERIOR. NOCHE.}

Rubén, camina solo por la calle desierta y se encuentra, al doblar una esquina, a María.

PABLO

Buenas noches, María

MARIA

Adiós, Pablo
Obviamente leer el texto anterior es mucho más árido que leer el siguiente:

El joven Rubén caminaba absorto en sus propios pensamientos en la oscura y angosta calle en medio de una noche oscura en la que no brillaba una sola estrella. Tal como estaba ensimismado, Rubén, al girar la esquina, casi choca con su compañera de clase María que con susto lo miró sorprendida. Rubén dio gracias a la oscuridad porque gracias a ella María no podría darse cuenta de su sonrojo y, con aspavientos, se limitó a saludar a María que, desconcertada, se despidió del raudo Rubén que se alejaba a toda velocidad.

El lector de una novela es guiado de forma directa por el escritor para que imagine lo que está narrando. ${ }^{\text {ii }}$ El lector de un guión necesita poner imágenes en la normalmente parca y sobria escritura del guionista que escribe unas imágenes que el lector debe ir construyendo en su imaginación (debe construir la película en su cabeza, previsualizarla). Además, obviamente, la finalidad de un guión no es su lectura. La finalidad de un guión es ser una herramienta de trabajo adecuada para que, usándolo (en toda la extensión de su significado), se construya una película de acuerdo con las decisiones que irá tomando no el guionista, sino, principalmente, el director y el productor de la película.

Más difícil todavía, ¿cómo convertir un texto tan magnífico como el siguiente en un guión?

La Señora Dalloway dijo que ella misma se encargaría de comprar las flores.

(Mrs. Dalloway said she would buy the flowers herself.)

Se trata, obviamente, del emblemático texto de Virginia Woolf, Mrs. Dalloway (Woolf, 2003: 17; 
versión inglesa 1993: 1). iii Narrar con palabras permite hacer algo tan complicado como narrar desde la mente de los personajes que, como dice Vargas Llosa (2003: 7-8), crea "un lenguaje capaz de fingir persuasivamente la subjetividad humana, los meandros y ritmos escurridizos de la conciencia." De forma que el "narrador de la novela está siempre instalado en la intimidad de los personajes, nunca en el mundo exterior. [...] Son las conciencias en movimiento" (Vargas Llosa, 2003: 11); pero el narrador desaparece en las conciencias de los personajes, transustanciándose con ellas, saltando de la una conciencia de un personaje a la de otro, combinando el estilo indirecto libre (inventado por Flaubert y consistente en narrar a través de un narrador impersonal y omnisciente) con el monólogo interior (perfeccionado por Joyce). El narrador se coloca tan cerca del personaje que parece confundirse con su misma conciencia, "que nos refiere sus pensamientos, acciones, percepciones, imitando su voz, su deje, sus reticencias, haciendo suyas sus simpatías y sus fobias, y es, por instantes, el propio personaje cuyo monólogo expulsa del relato al narrador consciente" (Vargas Llosa, 2003: 14), de forma que la primera y la tercera personas gramaticales dejan de ser contradictorias y forman, de facto, una sola. Woolf, como afirma Bloom (1995: 447), es un "modelo de esplendor persuasivo.”

Solamente ha habido un intento de adaptación de un texto tan complicado desde un punto de vista de guión. En 1997, Marleen Gorris dirigió la adaptación de la obra de Virginia Woolf ${ }^{\text {ivv }}$ con guión adaptado de Eileen Atkins; dos mujeres al frente del proyecto $^{\text {vi }}$ y con Vanessa Redgrave como Clarissa Dalloway. La película, lógicamente, articula su narración de forma muy diferente. La gran duda de un inicio tan potente como el de la novela Mrs. Dalloway es cómo expresar esa voz que nos informa de algo que atraviesa la conciencia de Clarissa: ¿usar un narrador extra/intra heterodiegético? $\mathrm{O}$, tal vez, ¿un narrador extra/intra homodiegético? He aquí una de las primeras decisiones que debe tomar el guionista (y que tiene que ver con la estructura narrativa del guión y, claro está, de la posterior película basada en él). La película, ${ }^{\text {vii }}$ sin embargo, da comienzo con una escena de guerra: trincheras en Italia 1918. Para, posteriormente, introducirnos en la casa de Clarissa, ella baja las escaleras sonriendo y se encuentra con su criada y a ella le dice que “compraré yo misma las flores, Lucy". La magia de la frase ${ }^{\text {viii }}$ de la novela se perdió totalmente (como se puede apreciar, la película reordena la historia). Una de las señales identificativas de la novela ya no existe en la película.

Y, rizando el rizo, podemos ver el ejemplo de un escritor que escribe una novela adaptando esa misma novela de Virginia Woolf, proponiendo no una nueva Clarissa, sino tres Clarissa(s), incluyendo en una de ellas a la misma Virginia Woolf. Tamaña hazaña la hizo Michael Cunningham con su magnífica novela The Hours (Las Horas) que ganó el Premio Pulitzer en 1999.

Todavía hay que comprar las flores. Clarissa finge exasperación (aunque adora hacer recados así), deja a Sally limpiando (...). ${ }^{\text {ix }}$

La señora Dalloway dijo algo (¿qué?) y fue a buscar las flores ella misma. ${ }^{\mathrm{x}}$

La señora Dalloway dijo que compraría las flores ella misma. ${ }^{\mathrm{xi}}$

Y para rizar más el rizo ya rizado, en 2002, ${ }^{\text {xii }}$ Stephen Daldry dirigió la adaptación cinematográfica homónima de dicha novela con guión de David Hare y con Nicole Kidman interpretando una Virginia Woolf que parece transmutada en la misma Clarissa Dalloway mientras escribe su libro y que desarrolla la acción en 1923 y 1941; con Julianne Moore, que interpreta a Laura Brown, una mujer casada frustrada en una calurosa California y que lee con pasión y enorme placer (¿el que no tiene en su vida?) Mrs. Dalloway en 1951 y que la vemos como una encarnación de la misma Clarissa; y, por último, con Meryl Streep como Clarissa, una tercera Clarissa contemporánea y que vive en Nueva York, en 2001, que se afana, como aquella, en preparar una fiesta de celebración. La película se construye con un guión estructurando en paralelo las tres historias (cfr. Hare, 2003). 


\section{VIRGINIA}

Mrs. Dalloway said she would buy the flowers herself. ${ }^{\text {xiii }}$

\section{LAURA}

"Mrs. Dalloway said she would buy the flowers herself." xiv

CLARISSA

Sally! I think I'll buy the flowers myself. ${ }^{\mathrm{xv}}$

No es el momento de hablar del juego de las adaptaciones pero la idea nítida es que es hay que repensar las historias considerando lo más adecuado para el medio cinematográfico (y para nuestro objetivo en él). Es fácil y deleitable enfrentarse con la narración, pero en cualquiera de sus formas, el guión es árido, poco elegante y cuya lectura exige el esfuerzo de una imaginación cinematográfica, porque el lector debe imaginar la película que hay inserta ahí no las imágenes particulares que cada uno pueda crear en su imaginación por la lectura de la narración. Volvemos a la idea base: el guión es un medio, no un fin en sí mismo.

Esa marcada finalidad de herramienta intermediadora es la que ha hecho que, usualmente, no se aprecie al guión (y, por ende, a su autor, el guionista) como una obra literaria en sí misma y, por ello, se le excluya (en un peculiar silogismo) de todo valor artístico. Pasolini hablaba de "el guión como estructura que tiende a ser otra estructura" y es que "todos los guiones encierran la dimensión de una 'técnica' autónoma, cuyo principal elemento estructural es la referencia que los integra en una obra cinematográfica que está por hacer" (en Guerin, 2004: 70). Es por eso que una cierta incomprensión rodea al guión y, por lógica, del mismo trabajo del guionista.

\section{3. ¿La obra del guionista es una obra audiovisual?}

Todo lo dicho hasta ahora no cual no tendría mucha importancia si no fuera porque tantas veces esa incomprensión de la que hablamos que envuelve al guión se ha trasladado (y se traslada) al mismo medio audiovisual; tantas veces ha sido (y es) la industria audiovisual la primera que ha ninguneado el trabajo de guión (el trabajo del guionista) y, poco menos, que lo ha (mal)usado como una mera guía para hacer la película y, por ello, por ser una "mera guía”, se la podía destrozar, recortar, cambiar y tergiversar.

Salvo que un escritor sea lo suficientemente afortunado como para ganar uno de los $[\ldots]$ premios [...] [importantes para guionistas], no hay nadie ajeno a la industria cinematográfica que, en alguna ocasión, haya tenido ni la más mínima idea de quienes son los guionistas. Cobran muchísimo menos que los actores principales o el director y sus nombres siempre aparecen, salvo contadísimas excepciones, muy discretamente en los títulos de crédito; lo que provoca, inevitablemente, que el nombre propio acabe "perdiéndose" y los espectadores lo olviden con gran facilidad.
Actualmente y desde siempre, la labor de los guionistas permanece en el anonimato. (Seger \& Whetmore, 2004: 21)

Tantas veces el guionista ha visto destrozado su guión o cómo se le cambiaba el sentido a la historia, cómo se manipulaban sus personajes, cómo se mutilaban argumentos y cómo se desvanecía el sentido último que quería haber transmitido con su historia y relato. $\mathrm{Y}$ no porque no tuviera sentido sino porque, en un momento dado, un director un tanto arrogante (y tantas veces nada lúcido) y/o un productor (un ejecutivo, más bien) con pocas luces (y perspectiva), era incapaz de entender, realmente, la historia que tenían delante de sus ojos.

Es por ello que, tantas veces, entre los guionistas, se suele decir que la principal virtud que debe poseer un guionista es la humildad. Porque sabe que una vez finalizado el guión y entregado (vendido), ya nada va a depender de él y que, incluso, puede pasar, que cuando se convierta en película, al propio guionista le puede resultar difícil (o imposible) reconocer, en dicha película, su propia historia, la que tanto tiempo le costó construir. Incluso, puede ser que ni siquiera figure en los títulos de créditos 
de la película porque (tantas veces en España) el director "ha hecho suya" la historia y (con atrevimiento) figura también como guionista (incluso, como "autor" de la "idea original"). A lo largo del tiempo me he encontrado con gente que tiene una reunión contigo (guionista) y te dicen, "quiero una comedia familiar". Y luego, gracias seguramente a dicha frase, aparece en los títulos de crédito como "idea original de" esa persona. Como afirma Parent-Altier (2005: 15), el guionista deberá aceptar que:

- su trabajo es una obra inacabada que se verá completada en el acto fílmico;

- si bien es autor de una película en papel (...) él no es el autor de la película;

- la desposesión de su acto creador -el pasaje de la escritura a la imagen- es indiscutible, pero que esto puede volverse tanto motivo de alegría como de angustia.

Tradicionalmente ha sido indignante cómo la industria cinematográfica ha tratado a los guionistas y a sus obras. ¿Cómo es posible que al guionista no se le considere cineasta si su trabajo da como origen la película y sin su trabajo no habría película? El guionista es escritor pero el guionista es también cineasta, es decir, un profesional de la industria cinematográfica (audiovisual). Tal vez por eso, actualmente, se encuentran refugiados muchos en las televisiones que les reconocen (y les dan) el poder de control sobre sus propias historias, convirtiéndoles en productores ejecutivos (me refiero especialmente a la televisión norteamericana, no tanta a la multi-realidad televisiva española que, según el caso, es muy diferente).

Algo tendría que aprender la industria cinematográfica. Y algo, tendría que aprender, muy significativamente, la industria cinematográfica española que adolece de una buena profesionalización de sus respectivos ámbitos de trabajo. Nunca he entendido muy bien la razón por la que en España es tan elevado el tanto por ciento de directores que "figuran", también, como guionistas. Es como si sintieran que si ellos no figuraran también como guionistas, su "autoría" se vería "mermada". ¿No es suficiente la autoría como director de la película? Tantas veces los fracasos y/o el no éxito de una película se ha debido a algo tan simple como que el director, por mucho que se empeñe, no es guionista. Obviamente no hablo de directores que son autores, que sienten la necesidad expresiva y creativa de escribir y rodar sus propias historias. Me refiero a que un director no tiene ninguna razón per se para pensar que si no escribe sus propios guiones (o si no figura como autor en ellos) su autoría audiovisual quedaría mermada, o sufrirá su posición intelectual y/o artística sobre la película, etc. Es completamente absurdo. La historia del cine está llena de grandes autores cinematográficos que, empero, no escribieron ni una línea de sus guiones (ni aparecieron como tales) y eso no deja de situarles en lo más alto de la creatividad y de la historia cinematográfica. ${ }^{x v i}$

Una industria que no valora cada uno de los sectores profesionales y creativos de su propia industria es una industria que nunca será tal industria. Y cuyos problemas no hay que buscarlos "solamente" en sus factores externos. En el caso español es especialmente grave en el trato a los guionistas. Tantas veces usados, tantas veces tratados como gente invisible. Tantas veces ni siquiera reconocidos en los títulos de créditos o que deben compartirlos con otra persona porque así se considera mejor comercialmente.

La industria audiovisual $(\ldots)$ tiende a apostar por el guión pero a no reconocer la función del guionista. Mientras que los guiones, precisamente por ser la base de lo que será el producto audiovisual, son muy buscados, lo son mucho menos los guionistas. (ParentAltier, 2005: 12)

Por no hablar de esa especie de autosuficiencia que hace que no se reconozca realmente en nuestra industria la labor de los analistas de guiones ni el trabajo de los coach de guionistas tan usados en otras industrias. Difícilmente en la industria norteamericana un guionista dejaría de acudir a un coach, a un consultor, a alguien que le ayude a ver que la historia y los personajes funcionan correctamente y que el guión no tiene ningún 
problema de estructura. Es como si un novelista no permitiera que un editor revisara su texto. Profesionalizar todos los ámbitos del guión y respetar el concepto de autoría debería ser solamente el inicio en el necesario cambio de actitud de la industria.

Y, obviamente, parte de dicho respeto es también pagar debidamente. Si se descuida, el guionista es el único profesional que no cobra (o el último en hacerlo) en una producción audiovisual. O cobra algo ridículo y no se le hace participe convenientemente en los beneficios que pueda generar su historia. Por no decir cuántas veces algún productor o director deja un guión a un profesional para que se haga un análisis, o para que se ayude al guionista con algunos consejos que sirvan para mejorar el guión y se lo pide como se lo pediría a su madre para que lo leyera para "ver qué le parece". xvii Es un trabajo profesional y, por lo tanto, hay que respetarlo y pagarlo como tal. Son cosas básicas pero que no se tienen en cuenta y no se solucionan. No obstante las cosas están mejorando, entre otras razones, gracias al asociacionismo de los propios guionistas, aunque aún lejos del poder del sindicato de guionistas en Estados Unidos. Supongo que leer esto no gustará a mucha gente de la industria. Seguramente los mismos que tanto debaten sobre los males de la industria en España, de los problemas de las descargas ilegales de Internet, etc., pero que ellos, en su propio ámbito, no están muy dispuestos a cambiar.

\section{4. ¿Existen los hábitos de guionista?}

Mucho tiene que ver también con cierto "carácter" que se suele adjudicar a los guionistas como personas con poco ego en un mundo de egos gigantes o, al menos, como personas con facilidad para la autocrítica despiadada y con poca seguridad en su trabajo (y, seguramente, en ellos mismos), siempre pensando que algo no cuadra, que algo falla, que algo no está del todo bien delineado. Parafraseando a Pennac (1993: 79-80) podríamos decir que escribir es un acto de resistencia. ¿De resistencia a qué? A todas las contingencias. Todas:

- Sociales.

- Profesionales.

- Afectivas,

- Climáticas.

- Familiares.

- Domésticas.

- Gregarias.

- Patológicas.

- Pecuniarias.

- Ideológicas.

- Culturales.

- O umbilicales.

Una lectura [en nuestro caso: una escritura] bien llevada salva de todo, incluido uno mismo.

$\mathrm{Y}$, por encima de todo, leemos [escribimos] contra la muerte. ${ }^{\text {xiii }}$
Contundente. Porque escribir nos salva de todo y a la vez nos hace resistir a todos los impedimentos y nos nutre y ayuda a "aplacar fundamentalmente nuestra sed de narración” (Pennac, 1993: 113). Por eso decíamos que el carácter, la psicología del escritor, del guionista, es peculiar, sensible, crítica y, tantas veces dubitativa. De ahí aquella frase de Bellow ${ }^{\text {xix }}$ : "Ha sido una pauta en mí, toda la vida, recuperar la fuerza desde una posición de extrema debilidad." (Roth, 2003: 199). Esa posición de extrema debilidad es la que provoca que cuando una productora se interesa por su guión, el guionista tiende a bajar la guardia y, por conseguir que se convierta en película, tantas veces está dispuesto a transigir con lo que la productora quiera. Por eso, mal vende los derechos sobre la historia. No se lee bien los contratos y renuncia, por documento firmado por él mismo, a aparecer en los títulos de crédito o que su historia se pueda cambiar completamente o que se pueda contratar a otra persona para que vuelva a escribir el guión ( $\mathrm{y}$ desplazarle en la autoría, claro está) o un larguísimo etcétera de casuística.

El guionista, decíamos, debe ser humilde porque sabe que su historia, en la fase de producción y postproducción cambiará, puesto que el guión es, como dice Vanoye (1996: 14), "un texto narrativodescriptivo escrito con vistas a su rodaje, o más 
exactamente a convertirse en filme”. ${ }^{x x}$ Pero también debería ser más decidido y no permitir ser ninguneado con tanta facilidad. El guionista, como cualquier otro trabajador "autónomo", debe esforzarse por conocerse bien y construir su propio oficio y su propia marca profesional (ha leído bien: "marca". En el fondo todos somos una marca $\left.{ }^{\mathrm{xxi}}\right)$. Es evidente que hay que escribir, escribir y escribir. Pero, como decía George Axelrod también debe leer $y \operatorname{leer}^{\mathrm{xxii}}$; visionar $\mathrm{y}$ visionar películas (recordemos: el guionista es un cineasta) y acudir al teatro; estar conectado con su público potencial y con su época; es decir, debe tener hábitos de trabajo, de estudio y de reflexión, porque "el hábito forma el estilo del escritor del mismo modo que forma el carácter del hombre" porque "el estilo (...) es disciplina" (Wharton, 2012: 30) y porque "para escribir bien, razonar es el principio y la fuente" (Horacio, verso 309: 136). Y no hay atajos. Puede parecer que uno no necesita ni leer tanto, ni visionar tanto ni reflexionar tanto. E igual consigue un blockbuster, lo imposible es que consiga un segundo. La profesión de guionista es un trabajo de fondo no de sprint. Por eso hay que fomentar hábitos de trabajo de larga duración. Si uno pretende algo rápido e inmediato, ésta no es buena profesión para él. Autocontrol, capacidad de trabajo sin supervisión, orden, capacidad de planificación, estudio, reflexión, intuición e ingenio son buenos hábitos para un guionista.

Lo primero que exige una obra de arte es entrega. Mirar. Escuchar. Recibir. Apartarse uno mismo del camino. (Lewis, 2000: 25)

Y al hablar de "hábito" quiero subrayar la capacidad de aprendizaje, la capacidad de ir mejorando día a día, es decir, de ir adquiriendo, si se permite el lenguaje clásico, de ir ganando en virtudes, que son imprescindibles para el desarrollo de una profesión, tantas veces árida y en la que se pasan, meses y meses, sin ver resultados ni saber si tanto trabajo terminará en algo o tendrá que desechar todo el trabajo realizado y volver a empezar o reorientarlo completamente; hay que tener en cuenta que, con facilidad, pasan un par de años para escribir y terminar un guión que pueda ser vendido (por eso también se puede intentar vender los derechos sobre la idea, sobre el tratamiento del guión y así poder financiar esos meses de trabajo de escritura).

Y, como siempre, en algún momento hay que empezar. Como afirmaba Wharton (2012: 79), "el arte de captar el momento justo es incluso más importante que la capacidad de presentar a un gran número de personajes al principio”. Y, siempre conviene recordar el consejo de Horacio (versos 3050: 124-125):

Emprender los que escribís un tema adecuado a vuestras fuerzas y reflexionad largo tiempo acerca de qué rechazan o qué aceptan llevar vuestros hombros. Al que haya elegido el tema a la medida de sus fuerzas no le abandonarán ni la facilidad expresiva ni el orden claro.

Paul Auster en su libro La noche del oráculo (2004: 9) nos presenta a Sidney, un escritor treintañero que después de un amplio periodo de inactividad por enfermedad, siente el impulso de retomar su tarea y, para ello, debe encontrar la nueva rutina que le permita aferrarse a ella y que, poco a poco, le permita volver a recuperar sus hábitos de escritura que le permitan reencontrarse con su yo de escritor. Auster nos abre a un tema (habitual en los libros de escritura) entre simpático y neurótico: las pequeñas manías que posibilitan al escritor seguir un procedimiento automatizado que le facilite ponerse a escribir, desarrollar y aprovechar su trabajo.

Escribir puede ser un arte pero, en cualquier caso, es un trabajo. Y como en cualquier trabajo se necesita la pericia necesaria para su desarrollo, la necesaria costumbre para sentarse y la capacidad de auto-exigirse para seguir escribiendo palabra tras palabra, frase tras frase. De ahí que haya que encontrar tiempo para poder pensar $y$, además, documentarse, escribir y, obviamente, encontrar la motivación para ponerse a ello. Sidney encuentra el motor inicial en unos fantásticos cuadernos de escritura portugueses $^{\text {xxiii }}$ que le devuelven las ganas de sentarse a escribir (Auster: 2002: 11 y siguientes). Llega a casa y organiza su pequeña habitación para que le facilite el trabajo (Auster: 2002: 19). Ordena la mesa, quita distracciones, organiza sus lápices y plumas y se enfrenta a la hoja en blanco del cuaderno portugués nuevo (dice 
Sidney: "me sentí como quien llega a casa después de un viaje largo y difícil, el desventurado viajero que vuelve para reclamar su legítimo lugar en el mundo"). Auster por medio de su personaje nos muestra la necesidad que tiene cualquier escritor de encontrar su propia rutina. Hay escritores que necesitan soledad, silencio y escribir mirando una pared; otros, sin embargo, escribir en bibliotecas silenciosas pero con gente; otros en cafés con más o menos bullicio pero que a ellos les permite abstraerse en su quehacer. ${ }^{\text {xiv }}$ No hay reglas. No hay formas mejores y otras peores. Cada cual debe encontrar lo que mejor potencie su imaginación, su capacidad de trabajo y concentración, a pesar de los nervios (tal vez constantes), del esfuerzo (prolongado) y de los momentos de placer en la escritura (que pueden parecer espejismos).

Es obvio que cuando uno comienza en su nueva profesión de escritor debe, poco a poco, encontrar su propio camino, lo que va desde su horario de escritura y su horario de lectura (e investigación) a, por ejemplo, como hemos visto, si primero escribe sus ideas en un cuaderno y luego las desarrolla en el ordenador o si escribe en su casa, en un café o en una oficina. Pero lo común a todo el mundo es que necesite un horario y una metodología de trabajo clara, definida y constante. Hay que obligarse, no vale (mala elección) trabajar a impulsos de las musas, que existirán o no, pero como no te pillen escribiendo de poco te van a servir. Escribir aunque sea como "ejercicio". Es decir, puede que no se tenga una idea clara. Es el momento en el que hay que escribir para ayudar a que fluyan las ideas. "Maurice Maeterlinck, un hombre cuyas creaciones le valieron un Premio Nobel, (...) dijo una vez: 'Tener ideas es un Paraíso, pero elaborarlas es un infierno'.” (Vale, 1996: 172). Como el personaje de Auster, Sidney, si no se tiene una idea clara (una línea argumental y/o un personaje claros) es el momento de plantearse un ejercicio:

Puse un cartucho de tinta en la pluma, abrí el cuaderno por la primera hoja y me quedé mirando la primera línea. No tenía ni idea de cómo empezar. El objeto del ejercicio no consistía en escribir algo concreto, sino en demostrarme a mí mismo que aún era capaz de escribir: lo que significaba que no importaba tanto lo que escribiera como el hecho de escribir algo. (Auster: 2004: 20)

Incluso puede ser que se empiece a escribir para desarrollar una idea que se cree lo suficientemente buena para que dé como resultado una buena historia que contar. Los primeros días puede que las cosas fluyan por el entusiasmo de la primera "luz" de la "idea" (lo que Nabokov llamaba "el primer latido", lo primero que surgía en él para construir su relato). Hay que aprovechar el impulso, porque la realidad es que, antes que después, el ardor desaparecerá, la idea se nos presentará como menos clara, con menos sentido y empezaremos a pensar que no era tan buena idea y que, por ese camino, no vamos a avanzar. La tentación perenne del escritor asalta: “¿no sería mejor no perder el tiempo y abandonar esta historia?" En el fondo, se nos termina de ocurrir otra cosa, que no tiene nada que ver con la anterior, pero que, en ese momento, nos parece mucho mejor... Con el tiempo, la escritora o el escritor saben que no es momento de abandonar sino de intensificar el trabajo. Que es el cansancio, el esfuerzo, lo que le hace dudar. Pero, pese a todo, hay que ser fiel a la historia. Y, otras veces, sabrá reconocer que, efectivamente, está llegando (o ha llegado ya) a un callejón sin salida y que es mejor "aparcar" esa historia (como nos cuenta Auster que le sucede a Sidney cuando su personaje termina encerrado sin posibilidad lógica de poder salir de ahí).

Hay muchos escritores que saben guardar esas historias inconclusas, tantas veces breves, porque en sí mismas no son muy valiosas pero que, con el tiempo, pueden encontrar un buen acomodo en futuras historias. Pedro Almodóvar contaba en noviembre de 2003 (Zurian, 2005: 482-484) cómo paseando vio un cartel que rezaba: "Dona Sangre" y que, de inmediato, pensó: "¿Qué bonito nombre de mujer! ¡Donna Blood!”; sacó su pequeña libreta de notas y lo apuntó. Al llegar a casa, empezó a escribir una posible línea argumental y en unos días desarrolló toda una historia breve de una chica que trabajaba en un almacén de sangre regentado por una secta vampírica. Y ahí quedó la cosa. Hasta que en 2009 todo el mundo pudo ver cómo Diego (Tamar 
Novas) le contaba a Mateo (Lluís Homar) la misma historia en Los abrazos rotos (Pedro Almodóvar, 2009) y Mateo le animaba a que escribiese esa historia. Una buena lección se puede extraer de esta anécdota: toda buena historia termina por tener sentido aunque, tal vez, tenga que esperar en el tiempo a que ese sentido llegue.

Nunca se pierde el tiempo ni las energías escribiendo aunque terminemos por desechar lo escrito. No solamente porque se pueda reciclar en el futuro, sino porque escribir eso, aunque en éste preciso momento no sirva, nos está haciendo mejores escritores. Otra buena enseñanza: es difícil que alguien que se dedica a escribir no lleve encima algo que le sirva para poder anotar una idea, un pensamiento, una frase que acaba de escuchar en el metro o anotar algo que ha visto o escuchado en la cafetería en la que está sentado leyendo (bien lectura para su investigación, bien lectura literaria). Complicado un escritor que no lleve siempre encima un bloc de notas (físico o electrónico) y un libro (también físico o electrónico).

Mi inspiración proviene de la vida real. Es como si la vida real me regalara la primera línea del relato y yo tengo que poner la segunda y si después consigo poner la tercera e incluso la veinte, ya tengo dos folios y si aquello me interesa, sigo. (Pedro Almodóvar en Zurian, 2005: 482)

Es muy parecido a lo que contaba C. S. Lewis de cómo nació en él la idea de El león, la bruja y el armario (de Las crónicas de Narnia ${ }^{\mathrm{xxv}}$ ) y fue

cuando se me pasaban por la cabeza ciertas imágenes. Al principio no había historia, sólo imágenes. El león empezó con la imagen de un fauno que llevaba un paraguas y unos paquetes por un bosque nevado. Llevaba grabada esa imagen desde que tenía unos dieciséis años. Luego, cierto día, cuando rondaba los cuarenta, me dije: 'Intentemos construir una historia a partir de esa imagen'.

Al principio no sabía en qué consistía la historia, pero entonces, de repente, apareció Aslan [el león] dando saltos. (...) [N]o sé de dónde salió aquel león ni por qué. Sin embargo, en cuanto llegó, comenzó a hilvanar la historia y, muy pronto, a hilvanar los otros seis libros de Narnia" (Lewis, 2004: 91)

Cada cual tiene su propia imaginación. A cada cual "las musas" le llegan de una forma distinta. Lo que hay que estar es despierto y no desperdiciar esas luces. Saber pensar en eso, saber darle vueltas sin dárselas.

Por supuesto, escribir es, a pesar de todo, una batalla. No importan las veces que lo hayas hecho. Te encierras en tu habitación, enciendes el ordenador y la lucha comienza una y otra vez. (Tom Schulman ${ }^{\text {xxi }}$ en Seger \& Whetmore, 2004: 40)

Hay escritores que funcionan mejor imaginando un personaje, otros una acción, ${ }^{\text {xxvii }}$ otros abriendo bien los ojos por las calles por las que caminan, otros soñando imágenes fantásticas, etc. Lo que sea. Lo importante es saber "mirar" (tener una mirada propia), estar atento, anotar, pensar, preguntarse cosas relacionadas con eso, volver a pensar, saber reposar y, escribir. Hay que escribir y escribir todos los días, aunque sea como ejercicio para hacer el necesario "músculo" (y hábito) que nos permita acometer la tarea con éxito. Lo contrario es como si un corredor solamente corriera cuando se presenta una competición interesante. Si hiciera tamaña insensatez, cuando se presentara dicha carrera no podría competir porque no estaría en forma, no tendría el hábito y no sería capaz de sacar de él mismo la energía y el coraje necesario para enfrentarse a dicho reto. Hay que entrenar todos los días. Con grandes carreras en el horizonte o sin ellas. Todos los días. Para que cuando se presente la posibilidad se pueda acometer. Todos los días. Constancia. Perseverancia. Capacidad de auto exigencia. Orden. Horario. Con ganas y sin ganas.

Eres un escritor, y un escritor escribe. Esto no significa que no luches, te demores, te sientas inseguro, te preguntes qué harás después, sientas confusión e incertidumbre $\mathrm{y}$ te preguntes si lo que has escrito tiene algún valor. Pero a pesar de todo, escribes. Lo haces porque 
tienes algo que decir, porque tienes historias bullendo dentro de ti, personajes que surgen en esas historias y cobran vida propia. Escribes porque tienes ideas que realmente te importan. Escribes porque tienes un fuerte deseo de decir la verdad. (Seger, 2001: 15)

Y hay que estudiar, hay que investigar, ${ }^{\text {xxvii }}$ hay que saber profundizar y no quedarse en la mera superficie de nuestros personajes y de nuestras historias porque "la resistencia a mirar el tema con suficiente profundidad conduce al indolente hábito de decorar su superficie." (Wharton, 2012: 51). Y a la profundidad hay que unir el tesón por hacerlo lo mejor posible, con todo el esfuerzo que eso significa de suyo.

A través del mundo se propaga un grito que brota del corazón del artista: ¡dejad que lo haga lo mejor que me sea posible! (Dinesen, 2006: 75)

\section{5. ¿Es posible escribir teniendo en mente la venta de lo escrito?}

Como decíamos, para un guionista, para cualquier escritor, su trabajo es escribir. Hay que escribir. Ese es su trabajo, es un trabajador de la escritura. Y, como en cualquier trabajo, si es tal, hay una remuneración. Por ello el guionista debe tener también claro que parte de su trabajo es vender lo que se escribe. Hay que conseguir que una productora (o una editorial) pague por esa historia. Los escritores suelen tener agentes literarios que se dedican a esa tarea de "venta", a gestionar los derechos y los contratos. Es mucho menos habitual eso en el mundo del audiovisual (español). Los guionistas deben la mayoría de las veces arreglárselas ellos mismos también con esas tareas. Por eso es importante que sepan gestionarse también como trabajadores autónomos, que sepan enfrentarse a una reunión con la productora, a un pitching, que sepan leer un contrato, que sepan negociar, que sepan exigir mejores condiciones, etc. Para todo ello son muy útiles los sindicatos de escritores audiovisuales (como, por ejemplo, ALMA: http://www.sindicatoalma.es) o entidades de gestión de derechos que tienen asesoría legal (como el SGAE: http://www.sgae.es).

Es muy importante que el guionista conozca la industria (recordémoslo una vez más: el guionista es un cineasta) y no ver a los ejecutivos como marcianos, como ajenos a él o a ella, sino verlos como lo que son: su llave para hacer realidad su guión; por eso, no es que escriba para ellos pero debe contar con ellos. Dejémoslo claro: escribe porque tiene la necesidad de contar su historia o, por ejemplo, siendo más pragmáticos, porque debe satisfacer un encargo - contrato- que le han hecho $\mathrm{y}$, en todo caso, escribirá más pensando en el público que en los ejecutivos de las productoras.

El guionista Akiva Goldsman lo tenía todo a su favor. El éxito de Batman y Tiempo de matar ( $A$ Time to Kill) le ha garantizado fama y fortuna al menos toda la fama y fortuna que puede llegar a tener un guionista de Hollywood-. Pero algo estaba incompleto. Goldsman se hizo a sí mismo la siguiente reflexión: "Si no escribo algo que sea muy especial para mí, estaré desperdiciando una enorme oportunidad" (Seger \& Whetmore, 2004: 19).

Y más tarde (o, en algunos casos, a la vez) pensando en el director elegido para la realizar la película. El guionista siempre debe tener en el horizonte a los ejecutivos, al director (si ya sabe quién va a ser) y (¡siempre!) al público (su público potencial). Es por eso que es muy importante que busque también ayuda profesional. De ahí la importancia (tan poco valorada en España) de los coach de guionistas (Seger, 2001: 213-215) que le ayudan a revisar el guión, desatascar alguna escena que no termina de funcionar, aconsejar sobre la estructura. Son una especie de "frontón" que le sirve al guionista para desenredar algo en el guión que se le ha atascado o descubrir algún posible problema que le ha pasado inadvertido pero, también, por ejemplo, para preparar bien el pitching con los ejecutivos de la productora.

En España, poco a poco, se va profesionalizando más el sector y se empieza a poder contar con 
representantes de guionistas (sin uno nadie puede trabajar en la industria norteamericana), analistas de guión (normalmente contratados por las productoras para seleccionar posibles guiones que puedan ser nuevos proyectos audiovisuales por desarrollar) y coach o consultores de guión (contratados por el guionista, pero muchas veces también por la productora, para ayudar a descubrir problemas de guión, bien en su estructura, en sus personajes o en la construcción de tramas, etc.).

Mientras el guionista no pueda contar con todas esas ayudas, deberá aprender a valerse por ella o por él mismo, y para eso es necesario, repetimos, que tenga "mentalidad" de industria que le permita crear (un guión), "venderlo" (y, para ello, negociar) y desarrollarlo (si es, por ejemplo, un piloto para televisión el guionista debe luchar por crear él el equipo de guionistas que le ayudarán a desarrollar los capítulos y será él que le dé identidad y continuidad al proyecto dirigiendo el equipo, liderándolo como creador y es eso lo que garantiza que haya un único punto de vista y no miles, en definitiva, el guionista se convierte en un Showrunner).

Como escritor, siempre tuve la esperanza de que, algún día, llegaría a escribir un guión que fuese tan brillante, que los productores pudiesen leerlo y entenderlo perfectamente sin necesidad de tener que conocerme ni mantener reunión alguna conmigo. De esta forma, evitaría el tener que acudir a las reuniones y dar explicaciones sobre mi obra, porque yo he sido realmente muy tímido. De alguna manera (...) me enfrenté contra el fantasma de mi propia timidez. (Tom Schulman en Seger \& Whetmore, 2004: 43).

Por eso insisto: los ejecutivos (de una productora y/o de una televisión) no son el enemigo; nadie conoce mejor cómo es su productora y sus productos) o su cadena de televisión que los de esa cadena de TV o los de la misma productora. ${ }^{\text {xxix }}$

\section{Conclusiones}

Recordemos algo de lo que hablábamos al principio y que nos sirve para rematar la idea de que el guionista es escritor, es un artista, un creador, pero también un cineasta, un miembro de la industria, los hábitos (virtudes) que el guionista debe fomentar en él (debe trabajarse): humildad, paciencia, decisión (para decidir qué quitar o por dónde ir en nuestro relato), talento, don de gentes, saber tratar gente y comunicar, cultura y saber estar... Y... ipasárselo bien! Escribir, puede ser duro, pero debe ser un placer, una satisfacción (intelectual y personal). Eso nunca debe olvidarse porque, con demasiada frecuencia, desgraciadamente, se puede caer en la creencia absurda de que escribir es un conjunto de normas (más o menos rígidas) que, como dice Amos Oz (2007: 137-139) ocultan tantas veces la realidad: la escritura es una necesidad y un placer, así como la lectura es, evidentemente, instructora pero también un placer.

Me gustaría terminar con una cita (pese a que es larga) del gran Stevenson (2006b: 139-141) cuando recomendaba al escritor joven (o novel) lo siguiente que:

Escoja un motivo, sea de carácter o de pasión; que construya cuidadosamente su trama, de modo que cada incidente sea una ilustración del motivo mismo, y que cada propiedad empleada tenga una cercana relación de congruencia o de contraste; que evite las subtramas, a menos que, como a veces en Shakespeare, la subtrama sea una inversión o un complemento de la intriga principal; que no tolere que su estilo caiga por debajo del nivel del argumento; que afine la clave de la conversación, sin pensar ni una sola vez en cómo hablan los hombres en los locutorios, sino mirando exclusivamente al grado de pasión que tenga que expresar y que no se permita en la narrativa, ni a ningún personaje en el curso del diálogo, decir una frase que no sea parte integrante de la trama del relato o la discusión del problema en cuestión. [...] Que no se preocupe perderse de mil cualidades si se mantiene inflexiblemente 
en busca de la que ha elegido. Que no se preocupe demasiado si pierde el tono de la conversación, el punzante detalle material de los modales del día, la reproducción de la atmósfera y del ambiente. Esos elementos no son esenciales: una novela puede ser excelente y sin embargo no tener ninguno de ellos; una pasión o un personaje están tanto mejor pintados cuanto más claramente surjan de las circunstancias materiales. [...] Y, en la raíz de todo el asunto, que tenga siempre presente que su novela no es una transcripción de la vida, a la que se deba juzgar por su exactitud, sino una simplificación de algún lado o aspecto de la ${ }^{x x x}$ vida, que se sostendrá o caerá según su significativa simplicidad. Pues aunque en los grandes hombres que trabajan con grandes motivos lo que observamos y admiramos a menudo es su complejidad, sin embargo, por debajo de las apariencias, la verdad permanece inmutable: que la simplificación fue su método y la simplicidad es su excelencia.

\section{Referencias}

- AUSTER, Paul:

(2002): AUSTER, Paul \& MESSER, Sam: La historia de mi máquina de escribir. Barcelona: Anagrama. Se trata de un libroarte(-y homenaje) con texto de Auster y fotografías de cuadros y dibujos de Messer de la máquina de escribir de Paul Auster.

(2004): La noche del oráculo. Barcelona: Anagrama.

(2012): AUSTER, Paul \& COETZEE, John M.: Aquí y ahora. Cartas 2008-2011. Barcelona: Anagrama \& Mondadori.

- BESANT, Walter: "El arte de la ficción" en BESANT, Walter; JAMES, Henry \& STEVENSON, Robert Louis (2006): El arte de la ficción. México D.F.: Universidad Nacional Autónoma de México. Se trata de una conferencia impartida por Besant en la Royal Institution (Londres) el 25 de abril de 1884.

- BlOOM, Harold (1995): El canon occidental. La escuela y los libros de todas las épocas. Barcelona: Anagrama.

- Chatman, Seymour (1990): Historia y discurso. La estructura narrativa en la novela y en el cine. Madrid: Taurus.

- COTRONEO, Roberto (1995): Si una mañana de verano un niño. Carta a mi hijo sobre el amor a los libros. Madrid: Taurus.
- CUNNINGHAM, Michael (2003): Las horas. Barcelona: El Aleph (original de 1998, The Hours. Nueva York: Farrar, Straus and Giroux).

- DINESEN, Isak (2006): El banquete de Babette. Madrid: Nórdica Libros.

- GRUBE, G. M. A. (1984): El pensamiento de Platón. Madrid: Gredos.

- GUERIN, Marie Anne (2004): El relato cinematográfico. Sin relato no hay cine. Barcelona: Paidós.

- HARE, David (2003): The Hours. Screenplay. Kent (UK): Faber and Faber.

- HORACIO: Poética. En la edición de Aníbal González Pérez (1982): Madrid, Editora Nacional. Que contiene, también, las poéticas de Aritóteles y de Boileau. Se citan primero los versos y, posteriormente, la paginación de ésta edición.

- HUET, Anne (2006): El guión. Barcelona: Paidós.

- LEWIS, C.S.:

- (2000): La experiencia de leer. Un ejercicio de crítica experimental. Barcelona: Alba.

- (2004): De este y otros mundos. Ensayos sobre literatura fantástica. Barcelona: Alba (original de 1982).

- MAMET, David (1995; $1^{a}$ reimpresión: 2000): Una profesión de putas. Madrid: Debate.

- McGRATH, Declan \& MacDERMOTT, Felim (2003): Guionistas cine. Barcelona: Editorial Océano. 
- OZ, Amos (2007): La historia comienza. Ensayos sobre literatura. Madrid: Siruela.

- PARENT-ALTIER, Dominique (2005): Sobre el guión. Buenos Aires: La Marca.

- PARKER, Philip (2003): Arte y ciencia del guión. Una completa guía de iniciación $y$ perfeccionamiento para el escritor. Barcelona: Ma non troppo.

- PENNAC, Daniel (1993): Como una novela. Barcelona: Anagrama.

- ROTH, Philip (2003): El oficio: un escritor, sus colegas y sus obras. Barcelona: Seix Barral.

- SEGER, Linda:

- (2001): Cómo llegar a ser un guionista excelente. Madrid: Rialp.

- (2004): \& WHETMORE, Edward J.: Cómo se hace una película. Barcelona: Ma non troppo.

- STEINER, George (1991): Presencias reales. ¿Hay algo en lo que decimos? Barcelona: Ediciones Destino.

- STEVENSON, Robert Louis:

- (2006a): El arte de escribir. [Conjunto de ensayos escritos entre 1881 y 1894.] Santa Cruz de Tenerife: Artemisa Ediciones.

- (2006b): "Una humilde amonestación" en BESANT, Walter; JAMES, Henry \& STEVENSON, Robert Louis: El arte de la ficción. México D.F.: Universidad Nacional Autónoma de México. El original se publicó a finales de 1884 en Longman's Magazine en respuesta a la conferencia de Besant y al textos de James citados anteriormente.

- TUBAU, Daniel (2011): El guión del siglo 21. El futuro de la narrativa en el mundo digital. Barcelona: Alba editorial.

- VAlE, Eugene (1996): Técnicas del guión para cine y televisión. Barcelona: Gedisa.

- VANOYE, Francis (1996): Guiones modelo y modelos de guión. Argumentos clásicos y modernos en el cine. Barcelona: Paidós.

- VARGAS LLOSA, Mario (1990): "La vida intensa y suntuosa de lo banal”, Prólogo en WOOLF, Virginia (2003): Mrs. Dalloway. Barcelona: Lumen. (Original de 1925).

- WhaRTON, Edith (2012): El arte de la ficción. Seguido de El vicio de la lectura. La guía clásica para el arte del relato y de la novela. Palma de Mallorca: José J. de Olañeta, Editor. Col.: El Barquero.

- WOOLF, Virginia (2003): Mrs. Dalloway. Barcelona: Lumen. (Versión inglesa 1993, original de 1925, cfr., por ejemplo, la edición: Londres, Nueva York y Toronto: Alfred A. Knopf, Everyman's Library).

- ZURIAN, Francisco A. (Ed.) (2005): Pedro Almodóvar, El cine como pasión. Cuenca: Ediciones de la Universidad de Castilla-La Mancha.

\section{Forma de Citación}

ZURIAN, Francisco A.: Sobre el oficio literario y audiovisual del guionista de ficción. Revista Communication Papers, N ${ }^{\circ}$ 6, páginas 98 a 113. Departamento de Filología y Comunicación de la Universidad de Girona. Recuperado el de de 2 de: http://www.communicationpapers.es

\footnotetext{
i "La inspiración llega realmente en los inicios de todo creador, pero las más de las veces llega como un niño pequeño, desvalido, balbuceante, inarticulado, al que hay que enseñar y guiar; y el principiante, durante el tiempo de adiestramiento de su don, lo más probable es que lo utilice mal, igual que un padre joven comete errores al educar a su primer hijo." (Wharton, 2012: 27).
}

ii Para no agotar al posible lector y lectora, y debido a la dificultad en español, nos referiremos a "el guionista" o "el escritor" como un genérico y no en su condición de género masculino, como si se excluyese a la mujer. Barajamos la posibilidad de usar "el/la guionistas" y otras opciones pero, realmente, resultaba dificultoso (y muchas veces complicado) de leer. Confiamos que ninguna posible lectora se sienta molesta (pedimos disculpas de antemano) y que los lectores tengan claro 
que la escritura (incluida la de guión) no es ni una actividad ni una profesión (como ninguna otra) en exclusiva masculina.

iii 1836-1901. Entre sus obras cabe destacar All in a Garden Fair (Rudyard Kipling afirmó en Something of Myself que tomó ésta obra como inspiración para hacerse escritor).

iv 1862-1937. De soltera Edith Newbold Jones. Su obra más conocida es La edad de la inocencia (The Age of Innocence) de 1920, que ganó el premio Pulitzer en 1921 y en 1923 fue la primera mujer nombrada Doctor honoris causa por la Universidad de Yale.

${ }^{v}$ Unas buenas herramientas son:

http://www.screenplaydb.com;

http://www.dailyscript.com/movie.html

http://www.simplyscripts.com y, sin duda, la colección de guiones editada por la editorial Ocho y medio libros de Cine (Madrid).

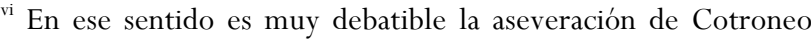
(1995: 37) cuando afirma que "en las novelas se pueden sentir los olores, en las películas no.” Steiner (1991: 151), analizando "la boutade de Gertrude Stein: 'there is no there there' ('ahí no hay ahí')", dice que "Los signos no transportan presencias." Pero en "el modelo postestructuralista y desconstructivo, es el lector quien produce el texto, el espectador quien genera la pintura." (Steiner, 1991: 156). O, podríamos seguir con el argumento, es el espectador quien genera la película.

vii Muy interesante el análisis de Chatman (1990: 81-82). Muy acertada su afirmación: "todo el libro es una celebración del recuerdo que se atrapa fugazmente entre el barullo de hoy en día [...]. En realidad, el recuerdo es la principal actividad narrativa" (Chatman, 1990: 82).

viii 1862-1937. De soltera Edith Newbold Jones. Su obra más conocida es La edad de la inocencia (The Age of Innocence) de 1920, que ganó el premio Pulitzer en 1921 y en 1923 fue la primera mujer nombrada Doctor honoris causa por la Universidad de Yale.

ix http://www.imdb.com/title/tt0119723/combined (consultado el 22 de junio de 2015).

${ }^{\mathrm{x}} \mathrm{Y}$ con Christopher Ball como productor ejecutivo principal.

xi Se puede ver la película subtitulada en: https: / / www.youtube.com/watch? $=6 \mathrm{e} 2 \_\mathrm{Kr} 2 \mathrm{jCRk}$

(consultado el 22 de junio de 2015).

xii Como afirmaba Stevenson (2006a: 19), en literatura es básica "la acertada elección y confrontación de las palabras utilizadas." Puesto que "cada frase, además, debe ser bella en sí misma, y entre la insinuación y el desarrollo de la oración debe darse un satisfactorio equilibrio de sonido; porque nada decepciona tanto al oído como una frase sonora y solemnemente dispuesta, con un final débil y precipitado. Pero el equilibrio tampoco debe ser demasiado notorio y exacto, ya que la regla principal estriba en ser infinitamente variado; en interesar, decepcionar, sorprender y, sin embargo, en recompensar al fin; estar, como si dijéramos, cambiando siempre la puntada pero sin dejar de dar la impresión de ingeniosa pulcritud." (2006a: 21, la cursiva es nuestra).

xiii La Clarissa neoyorquina y contemporánea (Cunningham, 2003: 15). xiv Cunningham recrea el momento en que Virginia Woolf escribe el magnífico inicio de su libro (Cunningham, 2003: 33).

${ }^{\mathrm{xv}}$ Laura Brown lee, en la cama, la novela Mrs. Dalloway (Cunningham, 2003: 39).

${ }^{x v i}$ http://www.imdb.com/title/tt0274558/ (consultado el 22 de junio de 2015)

xvii Secuencia 13 (Hare: 9).

xviii Secuencia 14 (Hare: 9).

${ }^{x i x}$ Secuencia 15 (Hare: 9).

${ }^{x x}$ Parent-Altier (2005: 7-10) cita ejemplos de directores tan destacados como los de Frank Capra (y su famoso Capra's touch), John Ford, Alfred Hitchcock, Howard Hawks; Robert Aldrich o Raoul Walsh y de sus guionistas, autores de tantas películas importantes en la historia del cine y, sin embargo, tan poco conocidos, como el caso de Robert Riskin, Dudley Nichols, Nunally Johnson, Charles Benet y muchos otros; por su parte Huet (2006: 10-11) transcribe una buena y larga lista.

${ }^{x x i}$ Seger (2001: 204).

xxii Pennac (1993: 169) también afirma que escribimos porque nos sabemos mortales, tal vez por aquello que se preguntaba Mamet (1995: 195): “¿Cómo puedo vivir en un mundo en el que estoy condenado a morir?".

xxiii Saul Bellow, escritor canadiense y estadounidense (19152005).

${ }^{\text {xxiv }}$ Conviene, de todas formas, no confundir el guión (literario, que aquí estudiamos) con el "guión técnico" elaborado sobre el guión literario por el director (y, muchas veces, por el productor, el director de fotografía, etc.) y que contiene tipos de planos, movimientos de cámara, efectos, etc.

${ }^{x x v}$ Peters, Tom (2000): 50 claves para... hacer de usted una marca. Bilbao: Ediciones Deusto.

xxvi "Leer no es una virtud; pero leer bien es un arte" (Wharton, 2012: 134) o, como escribía el gran crítico George Steiner (1991: 29), "Las mejores lecturas del arte son arte", pero para ello, "es en el interior, no en el exterior, donde debe estar el buen lector cuando lee.” (Oz, 2007: 139).

xxvii Sidney dice: "Los portugueses me resultaban especialmente atractivos, y con sus tapas duras, sus líneas cuadriculadas y sus pliegos de resistente papel cosido donde no se corría la tinta, en cuanto cogí uno y lo tuve entre las manos supe que iba a comprármelo." (Auster: 2002: 13). Auster nos habla también de los métodos de escritura. En su caso personal, él mismo, ha dedicado un texto a su propia máquina de escribir: "Ya llevamos juntos más de un cuarto de siglo. Donde quiera que haya ido, la máquina de escribir ha venido conmigo. (...) Todo se rompe, todo se gasta, al final todo pierde su sentido, pero la máquina de escribir sigue conmigo. Es el único objeto que me dura desde hace veintiséis años. Dentro de unos meses, me habrá acompañado exactamente la mitad de mi vida.” (Auster: 2002: 39-40).

xxviii Algunos ejemplos: Mario Vargas Llosa suele decir que le gusta escribir en bibliotecas; Nathan Englander, prefiere escribir por las tardes y en cafeterías o, al contrario, Adam Haslett se bunqueriza en su casa para estar totalmente aislado y en un ambiente ordenado y donde puede abstraerse de todo para poder concentrarse al máximo También hay quien prefiere irse, incluso 
de su casa, al campo, como le ocurre a Amy M. Homes que le gusta pasar largas temporadas en, por ejemplo retirada en Yaddo (http://yaddo.org), casa de retiro para artistas en Saratoga Springs, al norte del Estado de Nueva York. Sobre éstos tópicos recomendamos la serie documental sobre (y con entrevistas a) escritores que viven en Nueva York: "Scrivere/New York", http://www.minimumfaxmedia.com/production-ita-scriverenew-york.html (consultado el 22 de junio de 2015).

${ }^{\text {xxix }}$ Las crónicas de Narnia es una heptalogía de libros (1949-1954) que han sido (y aún lo son) enormemente populares entre los niños anglosajones. En homenaje a Las crónicas de Narnia, por ejemplo, son siete los libros de Harry Potter. El primer libro lo empezó en 1939 y terminó el último en 1949 (cuando C.S. Lewis tenía 51 años) publicándolo en 1950. La paciencia es otra gran virtud del escritor.

${ }_{\mathrm{xxx}}$ Guionista, por ejemplo, de El club de los poetas muertos (1989). xxxi Se suele hablar de "personaje-conductor" y de "historiaconductora". "Se considera que un guión pertenece al grupo denominado de 'historia-conductora' si está basado principalmente en un concepto muy elevado del argumento, que implica acción y conflicto (...). Por otro lado, se dice que un guión se circunscribe en las películas del tipo 'personajeconductor' si se centra, básicamente, en el desarrollo de los personajes y en los cambios que, durante el filme, experimentan sus personalidades.” (Seger \& Whetmore, 2004: 34).

xxxii "Investigación: todo está en los detalles" (Seger \& Whetmore, 2004: 27-30).

xxxiii Pamela Douglas, en How to Write TV Series, daba un buen consejo para quienes aspiren vender una serie de televisión: "Dos cosas básicas que los ejecutivos quieren y que tú debes prometerles: 1) La serie es única, original, nueva; 2) La serie es igual que otras que han triunfado.” (en Tubau, 2011: 81). 